\title{
ECONOMIC CULTURE IN THE CONTEMPORARY ERA: SOCIO-PHILOSOPHICAL ASPECT
}

\section{Yushkevych Yu. S.}

\section{INTRODUCTION}

The current state and further development of world civilization is determined by the complex globalization process. Integration transformations in all spheres of society, in particular, the formation of a single economic space, the unification of economic relationships and the emergence of universal economic interdependence are the result of this process. Awareness of this fact necessitated the consolidation of efforts to overcome the planetary challenges facing modern mankind.

The adoption of the United Nations Millennium Declaration in 2000, which defined the Millennium Development Goals until 2015, as well as the adoption in 2015 at the 70th session of the United Nations General Assembly of new guidelines for sustainable development until 2030, were the result of the desire to take constructive steps to the direction of solving the most pressing problems. In Ukraine, which is part of the United Nations, an inclusive process of adapting the Sustainable Development Goals for our state was founded too. The national report "Sustainable Development Goals: Ukraine", which contains an adapted version of 17 global goals taking into account national specifics, was prepared in 2017. It should be noted that the solution of problems that are specifically related to the economy of our country - overcoming poverty and hunger, reducing inequality, developing agriculture and innovative industry, ensuring decent work and economic growth, creating responsible consumption and production are of priority importance for the implementation of the main objectives of the strategy sustainable development of Ukraine ${ }^{1}$.

In our opinion, the existing formulation of sustainable development goals and a number of tasks that are designed to achieve

1 Національна доповідь «Цілі Сталого Розвитку: Україна». Київ: Міністерство економічного розвитку і торгівлі України, 2017. 
them contain a context whose theoretical disclosure requires not only a highly specialized purely economic point of view, but also a general humanitarian analysis.

The study of the concept of "economic culture" is quite effective in this context. From our point of view, the socio-philosophical approach to the study of economic culture has not found sufficient implementation in modern scientific discourse. However, it is precisely this approach that acts as a reference point in the boundless labyrinth of existing definitions.

However, it is precisely this approach that acts as a reference point in the boundless labyrinth of existing definitions, which allows one to see the most important, the most significant in this phenomenon, has methodological and system-forming purposes, and takes scientific research to another level.

Therefore, the socio-philosophical understanding of the essence and role of economic culture as an integrative form, which acts as the spiritual quintessence of economic life, the study of individual and supra-individual modes of its existence, the transformation of its contextual content, the definition of the ways of realizing the cultural and economic ideals of modern times at the social and individual levels is quite relevant.

\section{Economics and culture or economics as a culture: The essence and role of economic culture}

There are two opposing approaches - economic determinism and cultural determinism in philosophical and economic discourse. The most famous representatives of these approaches, in particular K. Marx and M. Weber, respectively, took extreme positions on the priority of the role of the economy or culture in the progressive development of society. According to K. Marx, culture arises in the process of economic activity of people, is built on the basis of which is the economy, and serves as a servant. The opinion of $\mathrm{M}$. Weber on this issue is fundamentally different than the previous one. He was convinced that a certain culture, in particular Protestantism, based on the values that appear as its content, forms such a motivation for behavior that directs representatives of this religious and cultural community to carry out economic activities based on market-capitalist 
principles. According to M. Weber, this is precisely what contributed to the formation of capitalist production relations.

It should be noted that the problem of the interaction of economics and culture, in particular the understanding of the phenomenon of economic culture, is still of fundamental importance in both theoretical and practical terms. This is of particular importance in the context of the need to eliminate factors that determine the crisis of the modern economy and the search for ways to improve the economic situation in Ukraine.

Representatives of modern economic and sociological thought, in particular D. North, note the significant influence of culture on the economy and insist on the need, in this context, to create a new integrated approach to the study of economic processes, which will consider economic, sociological, political, cultural aspects at the same time. In his opinion, the cognitive process of a person is not only influenced by culture and society, but is a cultural and social process in a fundamental sense. Outside of culture, which acts as a translator of knowledge and values, it is impossible to understand the specifics of the trajectories of economic development and the types of political and social structure of society. The study of the nature and dynamics of a specific institutional structure necessitates an appeal to the sphere of culture and understanding of the economy as a cultural process ${ }^{2}$.

In his report "Culture matters" A. Klamer notes that outside the economy there is a whole world that consists of values, virtues, from what is the foundation, encourages us to act and, more importantly, makes us people. In his opinion, economics is only part of the general context that culture is; it is only a tool for the production of what is more important, namely culture. We devote our whole life to the search for ideas, notes A. Klamer, that are part of our cultural goods, our accumulated cultural capital, which produces cultural values ${ }^{3}$.

In a sociological study of the economic culture of P. Berger, it was emphasized that economic institutions do not exist in a vacuum, but in the context of social and political structures, cultural forms and,

${ }^{2}$ Норт Д. Понимание процесса экономических изменений. М.: Изд. дом Гос. ун-та - Высшей школы экономики, 2010. С. 58.

${ }^{3}$ Кламер А. Культура имеет значение. Экономическая культура: иенности u uнтересы. Альманах центра исследований экономической культуры факультета свободных искусств и наук СПбГУ. С.-П. 2014. С. 13-19. 
of course, in the structure of self-consciousness: in systems of values, ideas, beliefs ${ }^{4}$. Therefore, they must be viewed through the prism of cultural and even axiological approaches.

On the other hand, it should be noted that the economy also has a significant impact on culture. Just as the objective conditions of life gradually, but purposefully form certain mental features of the nation, the current level of economic development sets objective parameters for the formation of culture of both individuals and social groups, and society as a whole. According to T. A. Petrushina, in the dialectical relationship of economy and culture, a constitutive role belongs to the material basis - the economy. The method of labor and production determines the coordinate system in which culture is formed and developed. It, in turn, is able to actively influence and determine further changes in the economic basis in the process of its development ${ }^{5}$.

Thus, the question of ascertainment of the determining role of one of the forms of social being of a person in the pair "economy-culture" remains open and even more relevant. Undoubtedly, the economy has cultural and even social roots; the available models of economic development depend on the type of dominant economic culture. The values and norms that constitute the content of this culture guide the economic development of society. In addition, the qualitative state of culture of the subject of economic activity, the level of formation of cultural and economic imperatives at the individual level, significantly affect the process and results of labor, both of an individual and the entire economic system as a whole. But the economy, in turn, determines the state and the further development of culture in its various manifestations. So, the economic component plays an important role in the possibility of implementing various cultural projects and preserving the cultural heritage, is a repository of the spiritual and material values of our people. Another aspect of this issue is that the economy in a certain sense acts as a "legislator", which determines the value content of the existing economic culture.

4 Бергер П. Капиталистическая революция: 50 тезисов о процветании, равенстве и свободе. М.: Прогресс-Универс, 1994. С. 31.

5 Экономическая культура населения Украины: Монография. Под ред. академика НАН Украины В. М. Вороны, д-ра филос. наук., профессора Е. И. Саименко. К.: Институт социологии НАН Украины. 2008. С. 17. 
The dialectic of the relationship of economy and culture is manifested in this. The progressive development of the modern economy is possible only if the content of the economic culture matches the market type of economy; otherwise, culture will conflict and slow down the development of the economic sphere. Therefore, this interaction is characterized by a certain cyclical nature, where a person is a connecting element as a subject of economic activity.

Abstracting from the purely instrumental aspect of this issue determines the expediency of not only recognizing the mutual influence of the economy and culture, but also determines the need to interpret the economy as a culture. According to A. A. Pogrebnyak and D. E. Raskov, an economy that is part of a person's cultural activity, which requires a search for a new vision of its subject field, will help to overcome the isolation of economic theory from moral, historical, social and even metaphysical contexts. Culture has a meaning-forming content. It refers to the fact that it is transcendental to the field of meanings of any abstract system that represents this or that nature, in particular economic relations, but is immanent to human existence in its specificity. In an economy that is viewed through the prism of culture, the subject is no longer a fixed agent that obeys certain objective laws. It is understood in the open historical horizon of continuous self-determination, within the framework of which standard economic goals are not something that certainly matters, but that always participates in the problematization of own meaning.

Returning to the question of determining the essence of the concept of "economic culture", it should be noted that the conceptual analysis of the existing definitions allows us to conclude that this concept is distinguished by the multivariate approaches to its study. This is the result of the multifaceted nature of this phenomenon. Spiritual and material, subjective and objective, individual and social, internal and external, and so on are related in it.

Relevant is the approach according to which, the cognitive, axiological and praxiological components are thought primarily in this concept. The cognitive element is a combination of knowledge and ideas that reflect various aspects of economic reality and form

6 Погребняк А. А., Расков Д. Е. Экономика как культура: возвращение к «спору о методах». Общественные науки и современность. 2013. № 2. С. 101. 
stereotypes of economic thinking. The axiological component includes material and spiritual values that function in the economic environment. The praxiological component is certain methods or vectors of activity of an individual, group or society as a whole; its purpose is the production, exchange and consumption of labor products; it is determined, on the one hand, by acquired knowledge and skills, and on the other, by acquired values, which are the content of economic norms that govern the behavior of subjects of economic relations.

Most scholars take moralistic or more abstract contexts into account when considering the value dimension of economic culture. Comparing the cognitive, axiological and praxiological components of economic culture, we tend to insist on the decisive role of the category "value" in the triad of "knowledge-value-activity", through which we can determine the essence and role of other elements.

The modern social space is characterized by the active development of post-industrial society and the formation of a new corresponding type of economy, namely the knowledge economy. The identification of the value content of this component of economic culture becomes possible as a result of studying the dual nature of knowledge. In this context, it is simultaneously a significant factor in the efficiency of modern production if it is innovative, and the result, the product of this economic activity. Knowledge is a set of external information that is abstracted from a specific intellectual producer, or internal knowledge-skills of a subject of economic activity. It is, on the one hand, a form of social being and self-realization of the individual and, on the other hand, the most valuable product on the market of post-industrial society. Therefore, it certainly has spiritual and material, as well as cultural and economic value.

In the context of the study of the axiological measurement of economic activity, it is also advisable to refer to the category of "labor". The valuable content of this phenomenon also manifests itself in two forms: as a result of labor activity - the accumulation of material wealth and as the intrinsic value of the labor process itself. The data of a sociological study of the specifics of the economic worldview of representatives of modern Ukrainian society indicate the following. The quantitative indicator of instrumental motivation is $45.4 \%$. In the framework of this motivation, labor is considered as a 
means of achieving certain goals and is not self-worth. A quantitative indicator of the value motivation to work, which is the opposite of the previous one, is slightly larger $-48.8 \%$. Pragmatic and social motivation to work - focusing on obtaining material profit $(64.5 \%)$ or pleasure from an interesting type of activity (24.9\%) - are directly related to the previous two forms of motivation ${ }^{7}$. In our opinion, such results indicate an imbalance in the economic worldview of modern Ukrainian and are also quite disappointing in the context of the worldview and philosophical tradition of our people. Remembering the philosophy of G. Skovoroda, namely the doctrine of "congenial work", it should be noted that only work that is close to your heart and gives the greatest pleasure can be most useful for a person on the path to achieving his own self-realization and personal happiness. It focuses the individual on the value-semantic content of culture and acts as a guarantor of the existence of a society of universal good.

A study of the value moralistic dimension of economic culture necessitates a reference to the work of D. McCloskey "Economics with Human Face or Humanomics", in which the economist famous in the United States of America calls for a critical review of the genesis of the economic order. The main idea of the author is that the developed countries of the modern world have achieved their success not due to the accumulation of capital or improvement of the private property system, but for completely different reasons, such as "the growth of the feeling of self-dignity of ordinary people and the feeling of freedom of inventors"8. D. McCloskey proposes to create an interdisciplinary sphere of economic knowledge - Humanomics, which will include ethical issues in the economic discourse. The subject of this science will be the virtues that are ignored within the standard approaches, but without which it is impossible to explain the richness of the modern world. According to the author, the return of economic issues to a wider context, which is associated with the transformation of spirit and values, can bring us closer to understanding how the development of modern civilization occurs.

Proponents of a similar point of view, cite as an example the success of the economic system of Japan, the basis of economic

\footnotetext{
7 Экономическая культура населения Украины. С. 135.

8 Макклоски Д. Экономика с человеческим лицом, или гуманомика. Вестник СПбГУ. Серия 5: Экономика. 2013. № 3. С. 40.
} 
activity of economic entities of which are moral and ethical values. According to the authors, the globalization and integration processes that determine modern economic development actualize certain social values, among which special attention should be paid to social justice and social responsibility ${ }^{9}$.

It should be noted that in the National Report "Sustainable Development Goals: Ukraine", which was discussed above, special attention is paid to the need to implement the principles of responsibility and justice in the economic sphere. Unfortunately, the data of sociological studies indicate a disappointing result for us. So, the majority of respondents $(63.1 \%)$ consider that pragmatic motivation predominates in the behavior of modern Ukrainian people - the desire to increase their material well-being at any cost. Only $6.4 \%$ of respondents say that representatives of our nation have a need for a mutual reward relationship - the desire for success on the basis of fair relations with others. Also, only $65 \%$ of experts note the presence of a formed feeling of responsibility at a level below the average and the existence of an economic culture of representatives of Ukrainian society as a whole ${ }^{10}$.

\section{Mental features of the formation of an economic culture of personality}

The economy and the economic culture of society are phenomena that mutually condense each other, interconnected with the help of subjects of economic activity, which in turn is a practical reflection of the economic consciousness of individuals. Therefore, a progressive change in the economic culture of society, first of all, determines the need to increase its level in each individual and the formation of the image of an "economic person" corresponding to the existing economic situation.

The search for ways of forming the economic culture of human, in particular its axiological component, necessitates the study of the process of the emergence of value orientations of a person. Cultural and economic values are to some extent the result of our own

9 Стожко Д. К., Стожко К. П., Целищев Н. Н. Аксиология современной экономики: проблема формирования экономического сознания. Вестник ПНИПУ. Социально-экономические науки. 2017. № 3. С. 260.

10 Экономическая культура населения Украины. С. 111; 114. 
experience, on the basis of which we evaluate, build a hierarchy, reevaluate and even devalue obsolete values. According to D. Dewey, certain preferences can receive the status of values if a person pays attention to them - is able to evaluate their desires ${ }^{11}$. Thus, a certain phenomenon can turn from a value opportunity into a value reality only in the process of a person's self-cognition.

It should be noted that the process of forming the axiosphere of an individual's economic culture takes on a more active form under the influence of external factors. These are the availability of adequate institutional conditions - the political stability of society, the innovativeness of management structures and their reorientation to support market relations, relevant legal regulation that can guarantee the safety of new economic activities - as well as the implementation of an effective system of economic education of the population that should carry out educational, upbringing and ideological functions. The most significant components of the educational system, as a set of channels for transmitting knowledge, which can change the individual's value orientations and increase the level of economic culture, are the educational institution, the family institution and the mass media. According to sociological studies, the institute of education has a constitutive role among them $-71.8 \%$, unlike others $59.8 \%$ and $36.8 \%$ respectively $^{12}$.

Turning to the issue of the content of educational activities, it should be noted that modern teachers face an extremely complex task - to change the existing value orientation of youth. Valorize such spiritual dominants as responsibility and justice, and also promote the process of reorienting students from the life paradigm "to be to have", which occupies a prevailing place in their minds ${ }^{13}$, to "to have to be", in the framework of which "possession" has only instrumental meaning in relation to "being", which is a terminal value. In addition, it is necessary to change the youth's perception of economic success, which is identified primarily with economic indicators $(31.4 \%)$ - the presence of a "big bank account", "own business" and "real estate that generates profit". Psychological indicators - "an interesting circle of

${ }^{11}$ Klamer A. A Pragmatic View on Values in Economics. Journal of Economic Methodology. June. 2003.

12 Экономическая культура населения Украины. С. 213.

13 Экономическая культура населения Украины. С. 102. 
contacts", "life in harmony with oneself and others", "satisfaction from ownership of the benefits received" and integral indicators "lack of feelings of unfulfillment and unnecessaryness", according to students, do not play a significant role in the life of a successful person $-16.3 \%$ and $9.1 \%$ respectively ${ }^{14}$. From our point of view, this is not true and may ultimately lead to the emergence of a state of existential vacuum in a human during certain periods of his life, which are characterized by the search for meaning-forming foundations of one's own existence.

It should be noted that the most fruitful form of valorization - the increase in value - of the object that serves the purpose of this process is a dialogue between the subjects that participate in its assessment. Thus, most representatives of modern economic discourse, in particular A. Klamer ${ }^{15}$, note that excessive theorizing should be avoided and seek dialogue during the teaching of economic science. The dialogue to a large extent includes valorization and encourages students to realize the value of the subject of discussion. A necessary condition for the effectiveness of this process is skillful coordination by the initiator, which is a teacher in the academic environment.

In this sense, philosophy has the greatest potential. It reproduces the basic mental traits and preserves the value core of the national ethnos, enriching it with the best examples of world culture. Philosophy is not a passive reflection of the mental features of an ethnos. The study of the philosophy that is the carrier of these essential features of the nation contributes to the preservation of mentality, its emotional and spiritual component.

The main focus in philosophy has always been on axiological and ethical issues. The content of this form of worldview, starting with the ancient classics, is the unity of three components: logic, physics and ethics. Revealing the internal connection of these elements, it should be noted that the organizing center in this triad is precisely ethics, which, as part of philosophy, is its unifying target. The most important

14 Москаленко В. В., Шайгородський Ю. Ж., Міщенко О. О. Економічна культура особистості: соціально-психологічний аспект. К.: Вид-во «Центр соціальних комунікацій», 2012. С. 200-201.

15 Кламер А. Странная наука экономика: приглашение к разговору. М.; Спб.: Изд-во Института Гайдара; Издательство «Международные отношения», Факультет свободных искусств и наук СПбГУ. 2015. 344 с. 
task of philosophical ethics is the understanding and the value design of philosophy itself as an ethical project - a morally worthy way of life. Ethics as a philosophy of morality is the expression, continuation and completion of the moral meaning of the whole philosophy without ethics there is no philosophy because it is itself ethics ${ }^{16}$.

Immersion in the depths of philosophical knowledge, where a person receives an impulse for a critical perception of reality that does not correspond to its own moral ideals, causes the construction in the mind of the individual of a mental image of the world, which is a sphere of dominance of moral and ethical values, a fair and dignified life. In the process of philosophizing, a person acquires skills of a skeptical attitude to social realities - forms a culture of doubt - and the desire not to stop at what has already been achieved on the path to the realization of an intellectual utopia, the goal of which is a morally perfect world.

Philosophical knowledge is a unique system of developing skills of non-dogmatic, flexible and at the same time evidence-based thinking. This is possible thanks to a peculiar toolkit of thinking - a problematic nature, multivariate answers, the use of cognitive, ethical and aesthetic abilities of consciousness of a person. Only within the framework of philosophy, as a result of elegant reflexive work on the development of ethically correct judgments, the moral component of social action is realized based on contextuality, not stereotypes. The content of this discipline, due to the non-declarative nature of it, is fruitful in developing independent thinking, searching for one's own moral position, and contributing to the realization of the individual's creative potential.

Studying philosophy, the student learns the skills of logically reasoned thinking and masters the culture of discussion, and also realizes the social and moral incentives of activity, which leads to the formation of a feeling of responsibility for its results.

Philosophy offers and solves issues that are quite general in nature; discovers, understands and formulates principles and laws that are significant for any area of human activity; helps to comprehend the meaning of human life itself. In addition, it develops the ability to navigate in the contradictions of public life, allows to constructively

${ }^{16}$ Гусейнов А. А. Философия как этический проект. Bопросы философии. 2014. № 5. C. 16-26. 
act in the development of strategic life positions, to compare, choose and justify values, landmarks and ideals. It provides an opportunity to overcome the fragmentation of knowledge, to achieve a holistic, universal vision of moral and ethical values. Thus, philosophy actually carries out the mission that, according to A. N. Whitehead, is central to it - to find a worldview that can save people from death, for which the most significant are values that go beyond meeting animal needs ${ }^{17}$.

Philosophy accumulates in a specific form the cultural and historical experience of mankind, which contributes to its transfer to new generations. The study of the philosophical heritage of mankind is one of the surest ways to attract the younger generation to generally accepted moral and axiological dominants. A variety of moral and ethical values that came to the fore in this or that historical epoch is perceived by a personality in the process of dialogical cognition, proceeding from its own spiritual needs.

The past of mankind, in particular its moral dimension, is like a mirror, from which a person can stop, step back and carefully peer into his own "I". The spontaneous formation of moral and ethical values of an individual occurs due to immersion in the historical past, in the course of one's own experience of moral images of different historical eras. So, according to V. S. Bibler, worthless should be considered attempts to force a person to behave like Oedipus, or to live like Christ; act like Hamlet or Don Quixote, since each of the moral situations requires from human to form his own version of morality and responsibility ${ }^{18}$. The reflection of the "disputing voices of historical eras" in the consciousness of a person makes it possible to understand himself and contributes to his spiritual growth.

The dialogical nature of philosophy contributes to the adoption of moral experience. Within the framework of philosophy, the historical past and the person who seeks to comprehend it are participants in subject-subject interactions. Philosophy provides an opportunity for the free choice of moral and ethical values relevant to the individual,

17 Уайтхед А.Н. Избранные работы по философии. М. : Прогресс, 1990. C. 560 .

18 Библер В. С. Нравственность. Культура. Современность : философские размышления о жизненных проблемах. Этическая мысль : науч.-публицист. чтения. М. : Политиздат, 1990. С. 17-19. 
which are the basis for the birth of her own spirituality, as evidence of the uniqueness of this act of creation.

Philosophical knowledge is characterized by reflexivity, due to the diversity of the considered worldview positions. Therefore, it helps students develop a sense of tolerance - acceptance of a different point of view. In the process of philosophizing, the opponent's judgments and arguments become clear, and understanding of the conceptual nature of knowledge as a whole is also achieved.

The process of self-determination and self-realization of human existence necessitates philosophical questioning. Human in essence must ask. He must create the human world himself, both as a separate individual and as a member of society. This requires personal knowledge. Philosophy immerses a person in the atmosphere of worldview questioning, which gives him orientation in life and allows him to find his place in the world. The basis for philosophical problematic issues is the cultural situation - a life situation in which eternal philosophical problems arise.

Philosophy contributes to the development of theoretical thinking, which helps to more deeply understand and master the special and theoretical disciplines today, and will also be the basis for the effective management of society in the future. In addition, the teaching of philosophy successfully solves the problems of developing students' understanding ability, which are the basis of both theoretical and practical activities. In this sense, philosophy is quite practical.

The practical component of philosophy is also realized in the framework of solving the question of the possibility of a free responsible act, which is the process of transforming theory into a mode of action; at the same time, it does not cease to be thinking, but is an act at the stage of its ideal formation in thinking. In the framework of the philosophical perception of practice, the behavior of the subject of moral relations is considered in its proper form, based on how it should be. Philosophy focuses primarily on the moral and not cognitive aspect of the act, considering it as a form of creativity. It combines not only theoretical and practical, but also a value attitude to the world.

The role of philosophy in the life of both an individual person and society as a whole is determined by the tasks that confront it, in particular, the preservation of the value paradigm of the realization of 
the process of cognition. Philosophy is the unity of the value and cognitive attitude to the world, therefore, it has great potential in solving the problem of finding forms of interaction of epistemology with axiology that correspond to the modern level of human development and society. This, in turn, contributes to the exit of society from the crisis state.

Philosophy, which is able to expand the information field of knowledge about ethical problems, stimulate moral reflection and develop the corresponding sensations, is the determinant of the formation of moral feeling. It plays a crucial role in the orientation of the individual towards moral self-improvement and development because it is a reflective form of knowledge. Her main duty and sphere of responsibility are values, in particular moral and ethical ones. It is philosophy that contributes to the formation of a sense of responsibility of a person for relatives, homeland and the fate of the world as a whole.

The implementation of moral and ethical values at the level of an individual subject involves passing certain stages. The formation of moral feeling is of the greatest importance among them. Knowledge of moral values generally accepted in society acquires an imperative character thanks to the moral feelings that arise during an emotional experience.

The specific of the process of obtaining moral knowledge largely excludes a logical explanation of moral and ethical values. Thus, J. Moore, using an original comparison of the concepts of "good" and "yellow," demonstrates the difference between the above forms of cognition and the incompetence of traditional means of communicative practice. He notes that just as it is impossible to explain what "yellow" is to someone who does not yet know what it is, it is also impossible in a similar situation to explain to him what "good" is 19 .

Moral cognition is distinguished by the personal attitude of the individual to social being ${ }^{20}$, and also involves a certain standardization of moral feelings. As a result of this, an "emotional generalization" of the social experience that a person has received within the framework

${ }^{19}$ Мур Дж. Э. Природа моральной философии. М. : Республика, 1999. С. 63.

20 Апресян Р. Г. Эмоциональные механизмы нравственности. Bonpocbl философии. 1981. № 5. С. 124. 
of communicative interaction occurs. Such a generalization helps to reflect the current moral and ethical values in the human mind and gives reason to talk about a certain consonance of the two methods of cognition - moral and artistic-figurative.

This specificity brings together moral and artistic knowledge. According to F. Schelling, art is able to comprehend all the facets of human existence - the inner world of a person with its joys and sorrows; therefore it is capable of what science is only trying to get closer to ${ }^{21}$. The artistic knowledge of moral phenomena is mainly carried out not in the abstract and due, but in the cultural and value aspects - in the categories of morality and relevant relations ${ }^{22}$. This form of cognition contributes to the comprehension of the social essence of the moral phenomena of society through concrete-sensual images of heroes and their actions.

The essence of moral problems is expressed in an understandable and close way to a significant number of people in the works of creative personalities. The master gives the opportunity to gain knowledge through his creation and at the same time contributes to the birth of a new truth that is enriched by personal and historical experience as a result of entering into dialogue through a work of art. Art is characterized by an art-shaped visualization of the image of the moral dimension of human existence. Thus, art can be considered the best way of transmitting moral knowledge and the necessary structural component of the formation of moral and ethical values.

Art is a means of transforming the practical and rational form of public perceptions of moral behavior into emotional and figurative. Therefore, it can be considered an effective way of symbolic reproduction of reality using an artistic image, as well as the transmission and reproduction of socially significant content in certain emotional states.

An artistic image is a metaphorical form of thinking that reveals one phenomenon through another and is characterized by a direct influence on the emotional sphere of a person. The formation of an artistic image involves the materialization of the artist's intention, his

21 Шеллинг Ф. Система трансцендентального идеализма. Л. : Соцэкгиз, 1936. C. 387.

22 Малахов В. А. Искусство и человеческое мироотношение. К. : Наукова думка, 1988. С. 113. 
subjective activity in the development of objective reality. The reader's perception of the artistic image involves the realization of the image in his mind in the form of subjective reality, which synthesizes in itself objective and real, as well as subjective and imaginary.

Thus, the need to apply an artistic-figurative interpretation of philosophical knowledge as a means of transmitting moral and ethical values is the result of the following factors. The formation of a moral feeling, as the determining component of a moral act and the conditions for the realization of moral and axiological dominants, is possible if moral experiences exist. Also, the need to take into account the specifics of moral cognition and mental characteristics of the Ukrainian ethnic group - the advantage of the sensory component and understanding of the world around us with the help of the "heart" necessitates the use of appropriate emotional mechanisms of influence on the individual's consciousness.

\section{CONCLUSIONS}

The need to take into account the individual and social levels of economic culture formation, in particular its value dominants, when planning the future strategy of economic development of Ukraine is the result of the determinism of the economy of our society by economic culture. Sociological data indicate an insufficient level of moral and ethical component of economic culture, in particular, a low degree of economic responsibility and economic justice. This can be a significant obstacle to the progressive development of our state as a worthy representative of the European community.

The desire to improve the state of the axiosphere of morality of modern Ukrainian society and the need to adjust the low level of development of the moral component of the economic culture of representatives of the Ukrainian ethnic group necessitates the search for optimal ways to implement moral and ethical values at the individual and social levels.

In modern conditions - the destruction of the institution of the family and the strengthening of the negative influence of the media of communication - the mission of the institution of education is the formation of the axiosphere of the personality and the direction of her spiritual energy to achieve her own moral perfection. Education is a significant mechanism for the translation of moral and ethical values 
and moral experience, as well as orientation to historically developed moral ideals that are fixed in the social consciousness.

Adequate functioning of morality in society provides for the interiorization of moral and ethical values - their adoption as their own - at the level of each individual. Based on the specifics of moral and ethical values and mental features of the Ukrainian nation, it is necessary to use such ways of their implementation that will not conflict with the internal nature of the representatives of the Ukrainian ethnic group and will allow to achieve a high level of morality in our society. The bearer of this potential, in our opinion, is a philosophy that, by virtue of its problematic, non-declarative, pluralistic, dialogical nature, represents the kingdom of freedom.

The use of an artistic-figurative interpretation of philosophical knowledge as a means of transmitting moral and ethical values is due to the need to form a moral feeling, as a determining component of a moral act and the conditions for the implementation of moral and axiological dominants, which is possible only if there are moral experiences.

\section{SUMMARY}

The article deals with the essence and role of economic culture in the development of the economy of modern society. In the context of understanding the phenomenon of economic culture, the problem of the interaction of culture and the economy is considered; the mutual influence and role identity of these two forms of social relations are substantiated. It has been defined that the main elements of the structure of economic culture are cognitive, axiological and praxiological. As a result of a study of the valuable and even moralistic dimension of economic culture, it is concluded that representatives of the Ukrainian ethnic group have a low level of economic responsibility. The institute of education was singled out as the optimal way to form moral and ethical values corresponding to the status of the European society. The article argues the position that the most appropriate, mental characteristics of the Ukrainian people and the specifics of the process of forming moral feelings, the channel for transmitting moral and ethical values is philosophy as a worldview and disciplinary form. The article also demonstrated that the artisticfigurative interpretation of philosophical knowledge is the most 
productive for activating the process of moral experience as a result of which a moral feeling is formed.

\section{REFERENCES}

1. Національна доповідь «Цілі Сталого Розвитку: Україна». Київ: Міністерство економічного розвитку і торгівлі України, 2017.

2. Норт Д. Понимание процесса экономических изменений. М.: Изд. дом Гос. ун-та - Высшей школы экономики, 2010. С. 58.

3. Кламер А. Культура имеет значение. Экономическая культура: иенности и интересы. Альманах центра исследований экономической культуры факультета свободных искусств и наук СПбГУ. С.-П. 2014. С. 13-19.

4. Бергер П. Капиталистическая революция: 50 тезисов о процветании, равенстве и свободе. М.: Прогресс-Универс, 1994. C. 31 .

5. Экономическая культура населения Украины: Монография. Под ред. академика НАН Украины В. М. Вороны, д-ра филос. наук., профессора Е. И. Саименко. К.: Институт социологии НАН Украины. 2008. С. 17.

6. Погребняк А. А., Расков Д. Е. Экономика как культура: возвращение к «спору о методах». Общественные науки и современность. 2013. № 2. С. 101.

7. Экономическая культура населения Украины. С. 135.

8. Макклоски Д. Экономика с человеческим лицом, или гуманомика. Вестник СПбГУ. Серия 5: Экономика. 2013. № 3. C. 40 .

9. Стожко Д. К., Стожко К. П., Целищев Н. Н. Аксиология современной экономики: проблема формирования экономического сознания. Вестник ПНИПУ. Социально-экономические науки. 2017. № 3. С. 260.

10. Экономическая культура населения Украины. С. 111; 114.

11. Klamer A. A Pragmatic View on Values in Economics. Journal of Economic Methodology. June. 2003.

12. Экономическая культура населения Украины. С. 213.

13. Экономическая культура населения Украины. С. 102.

14. Москаленко В. В., Шайгородський Ю. Ж., Міщенко О. О. Економічна культура особистості: соціально-психологічний 
аспект. К.: Вид-во «Центр соціальних комунікацій», 2012. C. 200-201.

15.Кламер А. Странная наука экономика: приглашение к разговору. М.; Спб.: Изд-во Института Гайдара; Издательство «Международные отношения», Факультет свободных искусств и наук СПбГУ. 2015. 344 с.

16.Гусейнов А. А. Философия как этический проект. Вопросы философии. 2014. № 5. С. 16-26.

17.Уайтхед А. Н. Избранные работы по философии. М. : Прогресс, 1990. С. 560.

18.Библер В. С. Нравственность. Культура. Современность : философские размышления о жизненных проблемах. Этическая мыслль : науч.-публицист. чтения. М. : Политиздат, 1990. С. 17-19.

19.Мур Дж. Э. Природа моральной философии. М. : Республика, 1999. С. 63.

20. Апресян Р. Г. Эмоциональные механизмы нравственности. Bопросы философии. 1981. № 5. С. 124.

21.Шеллинг Ф. Система трансцендентального идеализма. Л. : Соцэкгиз, 1936. С. 387.

22. Малахов В. А. Искусство и человеческое мироотношение. К. : Наукова думка, 1988. С. 113.

\section{Information about the author: Yushkevych Yu. S.,}

Candidate of Philosophical Sciences, Senior Lecturer at the Department of Philosophy, History and Political Science, Odessa National Economic University 8, Preobrazhenskaya str., Odessa, 65082, Ukraine 